\title{
Hambatan dalam Mewujudkan Open Defecation Free
}

\author{
Hilmi Sulaiman Rathomi, ${ }^{1}$ Eka Nurhayati ${ }^{1}$ \\ ${ }^{1}$ Departemen Ilmu Kesehatan Masyarakat \\ Fakultas Kedokteran Universitas Islam Bandung
}

\begin{abstract}
Abstrak
Open defecation free (ODF) merupakan salah satu target terpenting dalam Sustainable Development Goals (SDGs) yang ditujukan memutus rantai transmisi penyakit menular. Penelitian ini bertujuan mengetahui perilaku buang air besar sembarangan (BABS) yang masih dilakukan oleh masyarakat, sekaligus menganalisis berbagai faktor yang berpengaruh terhadap upaya eliminasinya menggunakan model behavior change wheel. Penelitian ini merupakan studi cross sectional dengan melibatkan 210 orang penduduk Desa Mangunjaya, Kabupaten Bandung yang dipilih secara cluster random sampling periode April 2017. Data diperoleh melalui wawancara menggunakan kuesioner tervalidasi, lalu dianalisis menggunakan software SPSS 20 dengan uji chi-square dan Spearman Rank Correlation. Hasil penelitian menunjukkan 28,6\% penduduk Desa Mangunjaya yang masih mempraktikkan kebiasaan BAB sembarangan 22,4\% penduduk yang tidak memiliki jamban. Ditemukan korelasi positif yang signifikan perilaku BABS dengan faktor motivasi $(\mathrm{r}=0,584)$, kemampuan $(\mathrm{r}=0,638)$, dan kesempatan $(\mathrm{r}=0,548)$. Terdapat perbedaan persepsi antara warga yang masih melakukan BABS dan yang tidak melakukan BABS mengenai faktor apa yang dinilai menghambat kepemilikan dan penggunaan jamban. Meskipun keduanya menyatakan bahwa faktor biaya adalah penghambatan utama, warga yang melakukan BABS cenderung menyalahkan lokasi desa sebagai hambatan terbesar kedua, sementara warga yang tidak BABS menilai bahwa kurangnya edukasi justru menjadi faktor terpenting selain hambatan biaya. Masih terdapat warga yang BABS dan tidak memiliki jamban dipengaruhi oleh faktor motivasi, kapabilitas, dan kesempatan. Peningkatan pengetahuan dan kepemilikan jamban perlu diupayakan lebih serius karena merupakan determinan terpenting pencapaian kondisi open defecation free di Desa Mangunjaya.
\end{abstract}

Kata kunci: Behavior change model, jamban sehat, open defecation free

\section{Barrier of Open Defecation Free}

\begin{abstract}
Open defecation free (ODF) is one of the most important target in Sustainable Development Goals (SDGs) that is intended to break the transmission chain of infectious diseases. This research aims to discover the open defecation (OD) behavior as well as to analyze factors that influence its elimination effort using behavioral change wheel model. This was a cross sectional study involving 210 villagers from Desa Mangunjaya, Bandung during April 2017 who were randomly selected with cluster random sampling method. Data were taken through interview using validated questionnaire, then analyzed using SPSS 20 with chi-square and Spearman rank correlation test. This research found there were 28.6\% of residents in Desa Mangunjaya who are still practising OD and 22.4\% do not have latrines. There was a significant positive correlation between OD behavior with motivational factor $(\mathrm{r}=0.584)$, capability $(\mathrm{r}$ : o.638), and opportunity ( $\mathrm{r}: 0.548$ ). There was a difference of perception between residents who were still practicing OD and who were not, on what factors are considered to inhibit the ownership and use of latrines. Although both placed the cost factor as the main barrier, residents who practicing OD tend to assess the location of the village as the second greatest obstacle, meanwhile the second group put the lack of education as a major factor in addition to cost constraints. The achievement of ODF condition in Desa Mangunjaya was inhibited by motivational, capability, and opportunity factors. Increasing latrines ownership and knowledge among villagers were very crucial, since they are the most important determinants.
\end{abstract}

Key words: Behavior change wheel, healthy latrine, open defecation free

Korespondensi: Hilmi Sulaiman Rathomi. Departemen Ilmu Kesehatan Masyarakat, Fakultas Kedokteran Universitas Islam Bandung, Jl.Tamansari no.22 Bandung, Email: hilmi.thomi@gmail.com 


\section{Pendahuluan}

Sustainable Development Goals (SDGs) yang sudah dicanangkan pada tahun 2015 menetapkan 17 tujuan pembangunan yang seharusnya dicapai oleh seluruh negara di dunia pada tahun 2030. Dibanding dengan agenda pembangunan global sebelumnya, Millenium Development Goals (MDGs), SDGs memuat banyak perubahan yang signifikan termasuk di dalam sektor pembangunan kesehatan. Dalam SDGs secara eksplisit isu kesehatan hanya ditempatkan pada tujuan ke-3, yaitu memastikan kehidupan yang sehat dan sejahtera bagi semua. Namun, pada kenyataannya, permasalahan kesehatan menempati porsi yang cukup besar dalam SDGs karena komponennya tersebar pada tujuan yang lain. Sebagai contoh, masalah gizi termasuk ke dalam tujuan ke-2 mengenai pengentasan kelaparan serta malnutrisi, masalah kesehatan reproduksi yang masuk dalam tujuan ke-5 mengenai kesetaraan gender, serta persoalan kesehatan lingkungan masuk dalam tujuan ke-6 mengenai akses air bersih dan sanitasi. ${ }^{1}$

Meskipun tidak secara eksplisit termasuk dalam isu kesehatan, persoalan mengenai sanitasi serta air bersih merupakan determinan amat penting bagi peningkatan derajat kesehatan masyarakat di seluruh dunia, termasuk di Indonesia. Sesuai dengan teori Blum, faktor lingkungan itu merupakan determinan paling penting bersama dengan faktor perilaku yang bahkan lebih esensial dibanding dengan keberadaan fasilitas pelayanan kesehatan. ${ }^{2,3}$ Keberadaan sanitasi yang layak dan akses air bersih akan memastikan masyarakat berada dalam lingkungan yang sehat dan mereduksi sebagian besar jalur penularan berbagai penyakit infeksi yang hingga saat ini masih menjadi beban besar baik secara kesehatan maupun ekonomi. ${ }^{1}$

Lebih dari 2,4 miliar orang di seluruh dunia tidak memiliki akses terhadap sanitasi yang layak. Secara global, sanitasi yang buruk berkontribusi sekitar 10\% dari beban penyakit, khususnya diare. Selain diare, pembunuh nomor satu balita pada saat ini adalah penyakit infeksi saluran napas juga dipengaruhi oleh kondisi sanitasi. Meskipun hal ini tidak secara langsung menyebabkan infeksi saluran napas, berbagai laporan menyatakan bahwa 26\% infeksi saluran napas bawah di antara anak yang malnutrisi berhubungan dengan riwayat diare yang dialami sebelumnya. Peningkatan kualitas sanitasi memiliki dampak yang signifikan tidak hanya pada aspek kesehatan, tetapi juga pembangunan sosial dan ekonomi, terutama di negara berkembang. ${ }^{4}$

Berdasar atas data dari Kementrian Kesehatan RI, lebih dari 1 dari 4 kematian pada usia balita disebabkan oleh lingkungan yang tidak sehat. Penyakit diare yang hingga saat ini manjadi salah satu pembunuh terbesar balita di Indonesia muncul oleh karena akses yang buruk terhadap air bersih dan sanitasi yang sehat. Sekitar 72\% kasus diare itu disebabkan oleh sanitasi buruk dan $46 \%$ di antaranya berujung pada kematian. ${ }^{5,6}$

Hal ini tentu memprihatinkan karena diare dapat dicegah dengan cara yang mudah, terutama melakukan perilaku yang mampu memutus mata rantai penularan dan kontak dari vektor penyakit ke makanan. Perilaku cuci tangan dengan sabun dan air bersih, konsumsi makanan yang bersih, serta terdapat fasilitas sanitasi yang sehat diperlukan agar sumber penularan penyakit tidak disebarkan oleh vektor kepada individu sehat. ${ }^{2}$
Salah satu target yang dicanangkan dalam SDGs terkait sanitasi yang sehat adalah akses universal terhadap jamban yang sehat dan pencapaian perilaku stop buang air besar sembarangan (BABS) atau open defecation free (ODF). Situasi ini diperlukan supaya tidak ada lagi penduduk yang turut menularkan sumber penyakit ke masyarakat di sekitarnya. ${ }^{7}$ Jamban sehat adalah jamban yang mampu mencegah kontaminasi ke badan air, mencegah kontak antara manusia dan tinja, membuat tinja tidak dapat dihinggapi serangga, mencegah bau yang tidak sedap, disertai konstruksi dudukannya dibuat dengan baik, aman, dan mudah. ${ }^{2}$

Berdasar atas profil kesehatan Indonesia 2015 , akses sanitasi layak penduduk Indonesia baru telah mencapai $62,14 \%$. Hal ini berarti lebih dari sepertiga penduduk Indonesia tidak memiliki fasilitas sanitasi yang memenuhi syarat. Penduduk yang melaksanakan praktik BABS juga masih cukup tinggi, yakni 17,4\% atau hampir mencapai satu dari lima penduduk. Di Provinsi Jawa Barat sebagai provinsi dengan jumlah penduduk terbesar, jumlah penduduk yang belum memiliki akses sanitasi layak lebih besar lagi, yakni mencapai $40,57 \%{ }^{6}$

Survei Enviromental Health Risk Assesment yang dilaksanakan oleh Dinas Kesehatan Kabupaten Bandung menunjukkan bahwa sekitar 11,5\% penduduk Kabupaten Bandung tidak BAB di jamban, melainkan di sungai, selokan, kebun, kolam, dan lubang galian. Pada warga yang BAB di jamban sekalipun, aspek saluran pembuangan masih menjadi masalah karena 51,8\% jamban tidak dialirkan ke septic tank. Lebih jauh lagi, berdasar atas laporan Puskesmas Banjaran mengenai situasi kesehatan Kecamatan Arjasari di Kabupaten Bandung, jamban yang sehat baru dimiliki sekitar 27,29\% rumah tangga. ${ }^{8}$

Penelitian ini dilaksanakan untuk mengeksplorasi perilaku BAB masyarakat yang sembarangan di Desa Mangunjaya Kabupaten Bandung dan faktor-faktor yang memengaruhi perilaku tersebut berdasar atas teori behavior change wheel model. Teori ini dipilih karena berorientasi pada upaya intervensi yang akan dilakukan berikutnya, yakni mengeliminasi hambatan terhadap terciptanya kondisi ODF di desa tersebut. Penelitian ini juga menganalisis persepsi masyarakat tentang faktor apa yang yang menghambat tercapainya ODF serta kepemilikan jamban yang sehat, baik dari sisi masyarakat yang masih mempraktikkan BABS, maupun yang sudah tidak mempraktikkan BABS.

\section{Metode Penelitian}

Penelitian ini merupakan studi cross sectional dengan sampel yang dipilih secara acak menggunakan metode cluster random sampling. Sebanyak 210 orang warga Desa Mangunjaya, Kecamatan Arjasari di Kabupaten Bandung terlibat sebagai responden dalam penelitian ini. Proses pengambilan data dilakukan selama bulan April 2017 dan melibatkan warga yang mempunyai status sebagai kepala keluarga, istri, atau anak dalam keluarga.

Pengambilan data dilaksanakan melalui wawancara menggunakan kuesioner yang tervalidasi mengenai karakteristik demografi warga, tingkat pengetahuan 
mengenai sanitasi, sikap mengenai sanitasi yang sehat, keberadaan fasilitas sanitasi itu dan karakteristiknya, serta perilaku sanitasi warga terutama dalam hal BAB. Wawancara juga dilakukan untuk mengukur persepsi warga mengenai hambatan yang dinilai menghalani kepemilikan jamban dan eliminasi perilaku BABS di lingkungan desa tersebut. Data dianalisis menggunakan software SPSS 20 dengan uji chi square dan Korelasi Spearman Rank dengan tingkat kepercayaan 95\%.

\section{Hasil}

Responden pada penelitian ini sejumlah 210 orang dengan rentang usia, tingkat pendidikan, dan status dalam keluarga yang berbeda-beda. Sebagian besar responden berusia 30-39 tahun merupakan kepala keluarga dan mempunyai tingkat pendidikan relatif rendah (SD). Berdasar atas penghasilan hanya sebagian kecil responden yang memiliki penghasilan bulanan di atas UMR Kabupaten Bandung sebesar Rp2.465.000,(34\%) yang menandakan status ekonomi warga Desa Mangunjaya tidak cukup baik. Rincian karakteristik demografi responden dapat dilihat pada Tabel 1.

\section{Tabel 1 Karakteristik Responden Penelitian}

\begin{tabular}{lcc}
\hline Karakteristik & n=210 & \% \\
\hline Usia (tahun) & & \\
$\quad<20$ & 5 & 2,4 \\
20-29 & 33 & 15,7 \\
30-39 & 65 & 30,9 \\
40-49 & 44 & 21,0 \\
$\quad$ 50 & 63 & 30,0 \\
Status responden & & \\
$\quad$ Kepala keluarga & 127 & 60,5 \\
$\quad$ Istri & 79 & 37,6 \\
$\quad$ Anak & 4 & 1,9 \\
Pendidikan & & \\
Tidak tamat SD & 6 & 2,9 \\
SD & 109 & 51,9 \\
SMP & 58 & 27,6 \\
SMA & 35 & 16,6 \\
Perguruan Tinggi & 2 & 1,0 \\
Penghasilan & & \\
$\quad$ Rp2.465.00o (UMR) & 71 & 34 \\
$\quad$ < Rp2.465.000 (UMR) & 139 & 66 \\
\hline
\end{tabular}

Masih cukup banyak masyarakat Desa Mangunjaya yang melakukan praktik BAB sembarangan, baik secara rutin maupun kadang-kadang. Secara keseluruhan, baik yang rutin $\mathrm{BAB}$ sembarangan maupun yang tidak rutin, jumlahnya mencapai $28,5 \%$. Jumlah ini lebih tinggi dibanding dengan angka BABS penduduk Indonesia, yaitu $17,4 \%$, serta jauh lebih tinggi dibanding dengan survei Dinas Kesehatan Kabupaten Bandung yang menyatakan bahwa sekitar $11,5 \%$ penduduk tidak BAB di jamban. Hal ini dimungkinkan terjadi karena tidak semua penduduk yang telah memiliki jamban telah secara konsisten meninggalkan praktik BAB sembarangan. Gambaran tingkat perilaku BAB warga Desa Mangunjaya dapat dilihat dalam Gambar 1.

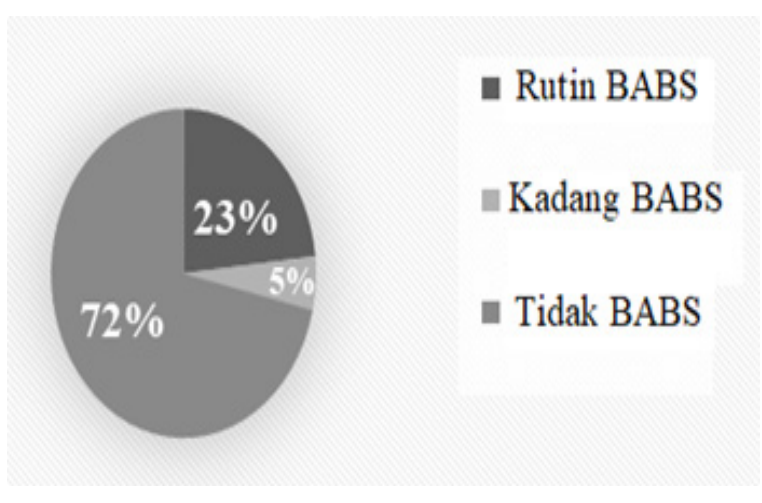

Gambar 1 Gambaran Perilaku BABS Warga
Desa Mangunjaya

Pengetahuan dan sikap warga mengenai sanitasi merupakan faktor penting yang menentukan perilaku kesehatan warga itu. Hasil penelitian terhadap tingkat pengetahuan dan sikap warga mengenai sanitasi dapat dilihat pada Gambar 2 berikut ini.

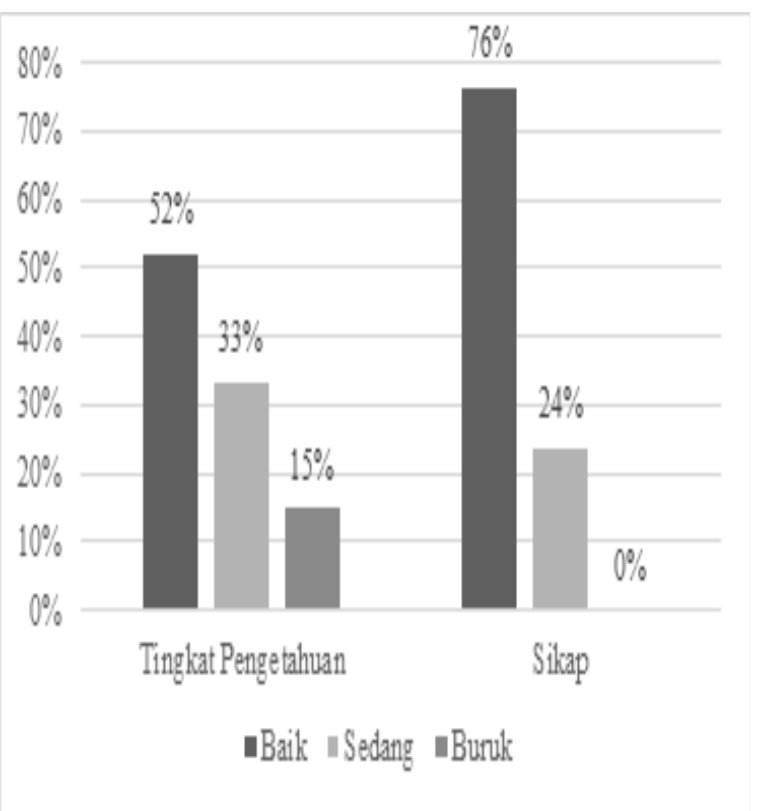

\section{Gambar 2 Distribusi Tingkat Pengetahuan dan Sikap Masyarakat Desa Mangunjaya Mengenai Sanitasi}

Gambar 2 memperlihatkan sebagian besar warga telah mempunyai tingkat pengetahuan dan sikap yang baik. Lebih dari setengah responden memiliki tingkat pengetahuan baik, sedangkan pada aspek sikap $76 \%$ sudah memiliki sikap terhadap sanitasi yang positif. Hal ini merupakan modal untuk mengadopsi perilaku tidak BABS. Terdapat warga yang masih mempunyai pengetahuan buruk merupakan faktor yang mungkin menghambat praktik sanitasi yang sehat, termasuk dalam hal BAB. 
Tabel 2 Tingkat Kepemilikan Jamban dan Karakteristik Jamban yang Dimiliki

\begin{tabular}{lcc}
\hline Karakteristik & $\begin{array}{c}\text { Frekuensi } \\
\text { n=210 }\end{array}$ & \% \\
\hline Keberadaan jamban & 163 & 77,6 \\
Ada & 47 & 22,4 \\
Tidak ada & & \\
Kepemilikan jamban & 144 & 68,6 \\
Milik sendiri & 20 & 3,5 \\
Milik bersama & 2 & 0,5 \\
Jamban umum & & \\
Jenis jamban & 154 & 93 \\
Leher angsa & 2 & 1 \\
Plengsengan & 2 & 1 \\
Cemplung tanpa lantai & 8 & 5 \\
Cemplung dengan lantai & & \\
Pembuangan & 152 & 92 \\
Tangki septik & 0 & 0 \\
SPAL & 9 & 5 \\
Kolam/sawah & 2 & 1 \\
Sungai/danau/laut & 3 & 2 \\
Lubang tanah & 0 & 0 \\
Pantai/kebun & & \\
Jarak septik tank & 30 & 20 \\
<10 meter & 122 & 80 \\
>10 meter & & \\
\hline
\end{tabular}

Tabel 2 memperlihatkan akses masyarakat terhadap fasilitas sanitasi. Akses terhadap fasilitas jamban pada penduduk di Desa Mangunjaya mencapai $77,6 \%$, di atas angka nasional yang hanya mencakup $62,14 \%$. Namun, dari seluruh fasilitas jamban yang digunakan oleh warga, tidak semuanya merupakan jamban sehat yang sesuai dengan standar layak. Hampir 1 dari 10 jamban yang digunakan warga bukan merupakan jamban leher angsa dan 20\% jamban tersebut dialirkan ke septic tank yang jaraknya $<10$ meter dari sumber air. Dengan demikian, masih ada peluang kontaminasi sumber air dari $\mathrm{BAB}$ warga yang dapat menimbulkan berbagai penyakit serius, terutama mengenai saluran cerna.

Tabel 3 Uji Korelasi Determinan Perilaku BABS

\begin{tabular}{lccc}
\hline Determinan & Nilai p & $\begin{array}{c}\text { Koefisien } \\
\text { Korelasi } \\
\text { (r) }\end{array}$ & $\begin{array}{c}\text { Kekuatan } \\
\text { Korelasi }\end{array}$ \\
\hline $\begin{array}{l}\text { Pengetahuan } \\
\text { (aspek }\end{array}$ & 0,000 & 0,638 & Kuat \\
$\begin{array}{l}\text { kemampuan) } \\
\begin{array}{l}\text { Sikap (aspek } \\
\text { motivasi) }\end{array}\end{array}$ & 0,000 & 0,584 & Cukup kuat \\
$\begin{array}{l}\text { Kepemilikian } \\
\text { jamban (aspek } \\
\text { kesempatan) }\end{array}$ & 0,000 & 0,548 & Cukup kuat \\
\hline
\end{tabular}

Tabel 3 memperlihatkan hasil uji korelasi yang menggambarkan kekuatan hubungan tiap determinan terhadap perilaku BAB yang dipraktikkan oleh warga di Desa Mangunjaya. Dari hasil uji statistik menggunakan Korelasi Spearman Rank, ketiga determinan itu, yakni pengetahuan, sikap, dan kepemilikan jamban memiliki korelasi yang kuat dan cukup kuat terhadap perilaku $\mathrm{BAB}$ warga.
Selain faktor-faktor kapabillitas, motivasi, serta kesempatan penelitian ini juga berupaya menggali faktor-faktor penghambat lain berdasar atas persepsi masyarakat. Faktor-faktor ini diukur memakai skala Likert (1-5) yang sebelumnya dirumuskan berdasar atas masyarakat awam, para tokoh, dan juga petugas puskesmas. Tingkat persepsi dari masyarakat tentang hambatan masih dilakukannya perilaku BABS serta masih terdapat warga yang tidak memiliki jamban di lingkungan Desa Mangunjaya dapat dilihat pada Tabel 4.

Tabel 4 Rerata \pm Standar Deviasi Skor Persepsi terhadap Faktor yang Menghambat Perilaku tidak BABS

\begin{tabular}{lccc}
\hline Keterangan & $\begin{array}{c}\text { Pelaku } \\
\text { BABS }\end{array}$ & $\begin{array}{c}\text { Non } \\
\text { Pelaku } \\
\text { BABS }\end{array}$ & $\begin{array}{c}\text { Nilai } \\
\text { p }\end{array}$ \\
\hline Kesadaran & $1,59 \pm 1,09$ & $2,35^{ \pm 1,39}$ & $<0,05^{*}$ \\
Dukungan & $1,12 \pm 1,36$ & $3,45^{ \pm 1.37}$ & $>0,05$ \\
Edukasi & $2,90 \pm 1,64$ & $3,50 \pm 1,36$ & $<0,05^{*}$ \\
Tingkat & $3,27 \pm 1,77$ & $3,33^{ \pm 1,45}$ & $>0,05$ \\
pendidikan & & & \\
Sumber dana & $4,45 \pm 1,08$ & $4,36 \pm 1,09$ & $>0,05$ \\
Lokasi desa & $3,73 \pm 1,47$ & $3,24 \pm 1,49$ & $<0,05^{*}$ \\
\hline
\end{tabular}

*terdapat perbedaan yang bermakna kelompok pelaku BABS dengan non pelaku BABS

Terdapat persamaan dan juga perbedaan tingkat persepsi masyarakat yang merupakan pelaku BABS dan nonpelaku BABS (Tabel 4).

\section{Pembahasan}

Penelitian ini menunjukkan jumlah responden yang melakukan perilaku BABS masih cukup banyak. Masih ada warga yang BABS dalam jumlah cukup tinggi ini harus menjadi perhatian. Dalam penelitian Gertler dkk. ${ }^{9}$ yang menganalisis tingkat keberhasilan program promosi kesehatan eliminasi BABS di India, Indonesia, Mali, dan juga Tanzania ditemukan bahwa pencapaian status desa ODF (o\% warga yang BAB sembarangan) mampu meningkatkan tinggi badan rerata balita di desanya masing-masing. Namun, bilamana perubahan status BABS tidak signifikan, upaya ini tidak akan sampai berdampak pada tinggi badan yang merupakan penanda status gizi kronik pada anak. Di desa yang berhasil mencapai ODF atau berhasil mengeliminasi perilaku BABS hingga tidak ada sama sekali akan meningkatkan tinggi badan anak sekiar 0,44 standar deviasi. Hal ini adalah bukti pentingnya aspek sanitasi dalam memperbaiki derajat kesehatan anak.

Determinan perilaku BAB warga dalam penelitian ini diukur dari sisi pengetahuan yang mencerminkan kapabilitas masyarakat, sisi sikap yang mencerminkan aspek motivasi, serta sisi kepemilikan jamban yang menggambarkan aspek kesempatan. Pendekatan ini dipilih mengacu pada behavior change wheel (BCW) yang merupakan pendekatan intervensi perubahan perilaku kesehatan yang dikemukakan Michie dkk. ${ }^{10}$ 
melalui proses systematic review terhadap berbagai kerangka intervensi perubahan perilaku kesehatan. Menurutnya, untuk dapat mengadopsi suatu perilaku yang diinginkan proses intervensi diperlukan untuk mampu menumbuhkan motivasi, kapabilitas, serta kesempatan (opportunity) pada target intervensi.

Sesuai dengan model dari BCW maka ketiga faktor tersebut perlu dimunculkan secara simultan supaya perilaku sehat yang diharapkan dapat dilakukan oleh masyarakat. Kapabilitas dan motivasi tanpa disertai kesempatan bagi warga untuk melakukan perilaku yang diharapkan tidak akan menjadi perilaku tersebut muncul di masyarakat dan begitu pula sebaliknya. Untuk mencapai ketiga hal itu perlu upaya intervensi secara langsung yang didukung oleh kebijakan di skala yang lebih besar. ${ }^{10}$

Akibat buruk dari rendahnya kepemilikan jamban dijelaskan oleh Semba dkk. ${ }^{11}$ dalam penelitian tentang hubungan keberadaan jamban sehat itu bagi rumah tangga dengan kejadian diare dan kematian balita di Indonesia. Dalam studi tersebut, baik pada penduduk di daerah urban maupun daerah rural didapatkan bahwa ketidakadaan jamban sehat akan meningkatkan risiko diare dan kematian pada balita.

Rajgire $^{12}$ dalam penelitiannya yang menganalisis 211 sampel sumber air minum secara bakteriologis serta mengukur water quality index mendapatkan perbedaan signifikan tingkat kontaminasi air yang berasal dari desa ODF dan non ODF, yakni $17 \%$ berbanding $48 \%$. Hal ini menandakan indikasi kuat bahwa perilaku BABS/open defecation amat berperan terhadap kontaminasi sumber air, baik pada susia, pompa, atau sumber air lain yang biasa digunakan untuk kebutuhan sehari-hari.

Fenomena perbedaan persepsi mengenai hal-hal yang menghambat tercapainya perilaku stop BABS antara warga pelaku BABS dan bukan pelaku BABS sangat menarik untuk diteliti lebih lanjut dengan mempertimbangkan faktor-faktor nonteknis seperti aspek budaya dan kebiasaan warga. Sesuai pendapat Engel dan Susilo ${ }^{13}$ dalam kajiannya yang menyatakan bahwa upaya intervensi eliminasi BABS saat ini merupakan pendekatan dengan menumbuhkan rasa malu yang justru merupakan pendekatan era kolonial dan tidak cukup berhasil di Indonesia. Indonesia sendiri kurang penelitian dari aspek kultural dan sosial yang lebih mendalam untuk mengetahui faktor apa yang mampu meningkatkan cakupan kepemlikan sanitasi masyarakat.

Dari penelitian ini juga tampak bahwa akses terhadap jamban tidak serta merta menghilangkan praktik BABS. Keadaan ini sejalan dengan penelitian Barnard dkk. ${ }^{14}$ yang mengevaluasi program kampanye sanitasi di India. Riset yang dilakukan Barnard dkk. ${ }^{14}$ memperlihatkan bahwa kampanye sanitasi berhasil meningkatkan cakupan kepemilikan jamban itu secara signifikan, namun lebih dari sepertiga (39\%) jamban yang diadakan tersebut tidak digunakan oleh anggota keluarga, bahkan 37\% melaporkan anggota keluarganya tidak pernah BAB di jamban. Dengan demikian, maka dapat disimpulkan bahwa perlu upaya yang tersendiri untuk dapat mengubah perilaku selain mengupayakan kepemilikan jamban untuk mengeliminasi kebiasaan BABS.
Dapat disimpulkan bahwa untuk warga dengan pengetahuan yang baik, sikap yang positif terhadap sanitasi serta memiliki jamban lebih cenderung untuk tidak melakukan praktik BABS. Dengan demikian, untuk merancang upaya intervensi eliminasi perilaku BABS di Desa Mangunjaya maka model BCW dapat dipergunakan dan berpeluang membantu mencapai hasil yang diharapkan.

Secara umum, keduanya merasa bahwa faktor biaya merupakan kendala utama kepemilikan jamban dan penyebab masih terdapat praktik BABS. Namun, kelompok masyarakat yang masih melakukan BABS cenderung untuk menyalahkan faktor lokasi dan tidak menilai kurangnya kesadaran, dukungan pemerintah, dan edukasi yang kurang sebagai hambatan utama. Sementara kelompok yang sudah tidak melakukan BABS menilai bahwa hambatan pencapaian ODF di Desa Mangunjaya adalah pada kesadaran, edukasi, dan dukungan pemerintah yang kurang.

\section{Simpulan}

Perilaku BABS masih cukup banyak dilakukan di Desa Mangunjaya Kabupaten Bandung dan hal tersebut disebabkan oleh faktor kemampuan dan motivasi yang perlu ditingkatkan, serta akses terhadap jamban sehat yang masih kurang. Model BCW dapat diterapkan untuk merancang upaya intervensi berikutnya, baik dalam rangka meningkatkan kepemilikan jamban maupun untuk mengurangi praktik BABS di wilayah tersebut. Diperlukan kajian lebih mendalam secara sosiokultural untuk mampu mengidentifikasi faktor lain yang berperan dalam eliminasi praktik BABS, membantu mencapai status desa ODF, dan memutus rantai penularan penyakit infeksi berbahaya yang menjadi beban yang besar, khususnya dalam upaya peningkatan derajat kesehatan anak dan balita.

\section{Daftar Pustaka}

1. Griggs D. From MDGs to SDGs: key challenges and opportunities [diunduh 13 Februari 2018]. Tersedia dari: https://sustainabledevelopment. un.org/content/documents/3490griggs.pdf.

2. Notoatmodjo S. Ilmu kesehatan masyarakat: Prinsip-prinsip dasar. Edisi ke-2. Jakarta: Rineka Cipta; 2003.

3. Undang-Undang Republik Indonesia Nomor 36 Tahun 2009 tentang Kesehatan.

4. Mara D, Lane J, Scott B, Trouba D. Sanitation and health. PLoS Med. 2010;7(11):e1000363.

5. Badan Penelitian dan Pengembangan Kesehatan, Kementerian Kesehatan Republik Indonesia. Riset kesehatan dasar (Riskesdas) 2013. Jakarta: Badan Litbang Kesehatan, Kemenkes RI; 2013.

6. Kementerian Kesehatan Republik Indonesia. Profil kesehatan indonesia 2016. Jakarta: Kemenkes RI; 2017.

7. United Nations General Assembly. Transforming our world: the 2030 agenda for sustainable development [diunduh 13 Februari 2018]. Tersedia dari https://sustainabledevelopment.un.org/ content/documents / 7891Transforming\%20 
Our\%2oWorld.pdf.

8. Puskesmas Banjaran Nambo, Kabupaten Bandung. Laporan tahunan hasil pencapaian program puskesmas banjaran nambo DTP. Banjaran: Puskesmas Banjaran Nambo; 2016.

9. Gertler P, Shah M, Alzua ML, Cameron L, Martinez S, Patil S. How does health promotion work? Evidence from the dirty business of eliminating open defecation. NBER Working Paper No. 20997. Maret 2015 [diunduh 13 Februari 2018]. Tersedia dari: https://www.nber.org/papers/w20997.pdf.

10. Michie S, van Stralen MM, West R. The behaviour change wheel: a new method for characterising and designing behaviour change interventions. Implement Sci. 2011;6(1):42. doi:10.1186/17485908-6-42.

11. Semba RD, Kraemer K, Sun K, de Pee S, Akhter $\mathrm{N}$, Moench-Pfanner R, dkk. Relationship of the presence of a household improved latrine with diarrhea and under-five child mortality in Indonesia. Am J Trop Med Hyg. 2011;84(3):44350. doi: 10.4269/ajtmh.2011.10-0244.

12. Rajgire AV. Open defecation: a prominant source of pollution in drinking water in villages. Int $J$ Life Sci Biotechnol Pharma Res. 2013;2(1):238-46.

13. Engel S, Susilo A. Shaming and sanitation in indonesia: a return to colonial public health practices? Dev Change. 2014;45(1):157-78. doi:10.1111/dech.12075

14. Barnard S, Routray P, Majorin F, Peletz R, Boisson S, Sinha A, dkk. Impact of indian total sanitation campaign on latrine coverage and use: a cross-sectional study in orissa three years following programme implementation. PLoS One. 2013;8(8):e71438. doi: 10.1371/journal. pone.0071438. eCollection 2013. 